\title{
Financial Reporting Quality, Free Cash Flow, and Investment Efficiency
}

\author{
Fusheng Wang ${ }^{1}$, Zhibiao Zhu ${ }^{1, a}$, John Hoffmire ${ }^{2}$ \\ ${ }^{1}$ School of Management, Harbin Institute of Technology, Harbin, China, 150001 \\ ${ }^{2}$ Said Business School, University of Oxford, Oxford, United Kingdom, OX1 5NY
}

\begin{abstract}
This paper based on the perspective of firm's agency conflicts to examine the relationship between financial reporting quality and investment efficiency and to analyze the interaction effect between financial reporting and free cash flow on investment efficiency. We use 3,726 samples of Chinese listed firms during the period 2008-2012 to test the empirical models and find that financial reporting quality is negatively associated with both underinvestment and overinvestment. Further, we find that financial reporting quality is more strongly associated with overinvestment for firms with large free cash flow, which suggests that financial reporting quality can reduce information asymmetry arising from agency conflicts between the managers and investors. This paper extends the field of application of financial reporting quality and investment efficiency in the emerging capital markets in the world. Moreover, this is the first study that analyzes the interaction effect between financial reporting quality and free cash flow on investment efficiency.
\end{abstract}

Keywords. financial reporting quality; free cash flow; investment efficiency; underinvestment; overinvestment

\section{Introduction}

This study examines the relation between financial reporting quality, free cash flows and investment efficiency for listed firms from emerging markets. In the neoclassical framework, the marginal value of an investment project is the only factor needed for firms to decide to invest or not (Miller and Modigliani, 1958). Thus, firm investment should not be related to internally generated cash flows and the access to external funds. But an increasing number of studies find that "noise" due to taxes and transaction costs will affect the validity of the market, and thus making the firm's investment deviate from the optimal level of investment. Information asymmetries and agency problems are the most common and important distorting factors that influence firm's investment efficiency in imperfect markets (Bushman and Smith, 2001). However, financial reporting is generally considered to be an important tool to reduce information asymmetries and mitigate agency problems. Recent papers (Biddle and Hilary, 2006; Biddle, Hilary, and Verdi, 2009; Betty, Liao, and Weber, 2010; Chen et al., 2011; Ramalingegowda, Wang,

\footnotetext{
${ }^{\text {a }}$ Corresponding author: zhibiao.zhu@hotmail.com
} 
and $\mathrm{Yu}, 2013$ ) suggest that enhanced financial reporting quality can have important economic implications such as increased investment efficiency in developed countries. Also, some papers show that free cash flow can be associated with investment efficiency (Jensen, 1986; Stulz, 1990; Shleifer and Vishny, 1997). Despite a growing number of papers in this area, little research directly examines whether financial reporting quality alleviates overinvestment for firms with large free cash flow. Therefore, there is necessary and important to research on financial reporting, free cash flow and investment efficiency in emerging capital markets.

We posit that financial reporting plays an important role in mitigating both underinvestment and overinvestment, especially reduce overinvestment for firms with large free cash flow. On one hand, financial reporting quality reduces information asymmetry by providing more information to investors on the firm's investment projects, thereby reducing adverse selections at the issuance of securities (Bushman and Smith, 2001). On the other hand, financial reporting quality mitigates moral problems by facilitating contracting and monitoring (Healy and Palepu, 2001). In addition, the managers in firms with free cash flow incline to overinvestment. However, firms with higher financial reporting quality create a negative impact of inefficiency investment by enhancing the ability of shareholders to monitor managers and improving project selection. Therefore, we hypothesize that financial reporting quality is negatively associated with both underinvestment and overinvestment ( $\mathrm{H} 1$ and $\mathrm{H} 2$ ). Further, we expect the mitigating role of financial reporting quality to overinvestment for firms with large free cash flows (H3).

We measure investment efficiency as deviations from expected investment which is a function of growth opportunities and financial reporting quality using the modified Dechow and Dichev (2002) model. We estimate free cash flow using an accounting-based framework which is introduced by Richardson (2006). Based on a large sample of 3,726 firm-year observations from 2008-2012 in China, we find that financial reporting quality is negatively associated with both underinvestment and overinvestment. Further, financial reporting quality is more strongly associated with overinvestment for firms with large free cash flow, which suggests that financial reporting quality can reduce the information asymmetry between managers and investors and thus lower shareholders' cost of monitoring managers and improving project selection.

Our study contributes to two aspects of literature. First, it contributes to expand the research that examines the relation between financial reporting quality and investment efficiency from emerging capital markets in the world. Most prior studies are based on markets which are mature and standardize in the developed countries (Biddle and Hilary, 2006; Biddle, Hilary, and Verdi, 2009; Ramalingegowda, Wang, and $\mathrm{Yu}, 2013)$; this paper extends the field of application of financial reporting quality and investment efficiency. Second, this is the first study that analyzes the interaction effect between financial reporting quality and free cash flow on investment efficiency and it reveals that financial reporting quality is more strongly associated with overinvestment for firms with large free cash flow. Most prior studies are focus on direct impact between financial reporting quality and investment efficiency (Biddle, Hilary, and Verdi, 2009). There is little research that examines how financial reporting quality impacts investment efficiency in different types of firms with different free cash flow.

The remainder of the paper proceeds as follows. Section 2 develops the hypotheses. Section 3 describes the measurement of investment efficiency, financial reporting quality and free cash flow. Section 4 presents the research design and results. Section 5 concludes the paper.

\section{Hypothesis development}

\subsection{Financial reporting quality and investment efficiency}

Recently there are a large of literature have been developed on the effects of financial reporting quality on investment efficiency (Bushman and Smith, 2001; Healy and Palepu, 2001; Biddle and Hilary, 2006; Hope and Thomas, 2008; McNichols and Stubben, 2008; Biddle, Hilary, and Verdi, 2009; Ramalingegowda, Wang, and $\mathrm{Yu}, 2013$; Balakrishnan et al.(2014). Financial reporting 
quality can be associated with investment efficiency though at least two channels. First, financial reporting conveys firm specific information to investors and reduces information asymmetry between the firm and investors and among investors. Thus, it could mitigate adverse selection costs and reduce the costs of raise capital (Verrecchia, 2001). For example, Leuz and Verrecchia (2000) show that firm disclose more information to increase liquidity by reducing information asymmetry between the firm and investors. On the other hand, the existence of information asymmetry between the firm and investors could lead suppliers of capital to discount the stock price and to increase the cost of raising capital because investors would infer that firms raising funds are of a bad type (Myers and Majluf, 1984). Therefore, financial reporting quality mitigates information asymmetry and increase investment efficiency by reducing the costs of external financing for firms (McNichols and Stubben, 2008). Second, it is common argued that financial reporting quality plays an important role in mitigating agency problems between the managers and investors. For example, compensation contract is always based on financial information (Lambert, 2001) and is an important source of information used by investors to monitor managers (Bushman and Smith, 2001). In addition, financial information contributes to the monitoring role of stock markets as an important source of firm-specific information (Kanodia and Lee, 1998; Healy and Palepu, 2001). Therefore, if financial reporting quality reduces agency problems between the managers and investors, it can then improve investment efficiency by increasing shareholders' ability to monitor managers and thus reduce financing costs and improve project selection.

Based on the discussion above that financial reporting quality affects both adverse selection and agency conflicts, we follow the approach of Gomariz and Balleata (2014) to test whether financial reporting quality from emerging markets helps mitigate both underinvestment and overinvestment. In other words, we investigate financial capital investment inefficiencies under less conductive conditions than those examined in prior research. The above discussion leads to our hypotheses as follows:

H1: Financial reporting quality is negatively associated with underinvestment.

$\mathrm{H} 2$ : Financial reporting quality is negatively associated with overinvestment.

\subsection{Financial reporting quality effect on investment efficiency conditioned to free cash flow}

In a world of perfect capital markets, there are no information asymmetries, no moral hazard problems, no taxes and no frictions for raising external finance. Thus, there would be no association between corporate investment and internally generated cash flow. For example, if a firm needed cash to finance an investment project it would simply raise that cash from external capital markets; if the firm had excess cash beyond that needed to fund projects with positive net present value (NPV), including options on future investment, it would distribute free cash flow to shareholders and external markets. However, firms do not operate in such a world. There exists a variety of capital market frictions such as information asymmetries and agency problems which constrain firms to raise cash from external capital markets and constrain managers to use cash to engage in valuable projects. In addition, it is difficult for external capital providers to monitor management, which creates the potential for management to spend internally generated cash flow on projects that are beneficial from management perspective but costly from a shareholder perspective. This free cash flow hypothesis was introduced by Jensen (1986) and Stulz (1990). It means that there should be a positive relationship between firm investment and internally generated cash flow. Several papers have investigated the implications of the free cash flow hypothesis on firm investment. For example, Lamont (1997) and Berger and Hann (2003) find that firms with much cash prefer developing to diversified firms. Harford (1999) investigates 487 takeover bids and finds that firms with rich cash are more likely to make acquisitions. Opler, Pinkowitz, Stulz and Williamson (2001) find that firms with excess cash have higher capital expenditures and spend more on acquisitions, even when they appear to have poor investment opportunities. The positive relationship between firm investment and internally generated cash 
flow could be due to several factors such as perquisite consumption (Jensen and Meckling, 1976), diversifying acquisitions (Morck, Shleifer, and Vishny, 1988, 1990), empire building (Shleifer and Vishny, 1997) and subsidizing poorly performing divisions using the cash generated from successful ones instead of returning the cash to shareholders (Berger and Hann, 2003; Jensen and Meckling, 1976; Lamont, 1997). All these evidences could reflect management engaging in additional investment on self-serving projects rather than distribute the cash to shareholders.

Financial reporting can reduce information asymmetry between the managers and the investors and thus lowers the shareholders' cost of monitoring managers. Firms with free cash flow have more opportunity to engage in value destroying investment activities, which indicates that firm with overinvestment has a high likelihood of agency problems. Therefore, financial reporting quality can play a more important monitoring role in mitigating agency problems for these firms. This discussion motivates our final hypothesis:

H3: The relation between financial reporting quality and overinvestment is stronger for firms with large free cash flow.

\section{Sample and Measurement of Main Variables}

\subsection{Data Source}

Our financial data needed to test this paper is from one of China's stock market Shenzhen Stock Exchange (SZSE) and the China Stock Market and Accounting Research (CSMAR) database. We manually collect the nature of equity according to the annual financial reports of individual firms. The sample selection process is as follows. Firstly, considering our research purposes, we exclude financial firms because their general characteristics are much different from common listed firms. Secondly, we exclude the firms which are restructuring assets and changing equity. Thirdly, we exclude the firms for which data is incomplete. Last, based on the A-M industry classification standard in China, each industry requires at least 20 observations each year. Therefore, we get 3,726 samples during the period from 2008 to 2012 .

\subsection{Proxy for Investment Efficiency}

Investment efficiency refers to firms that undertake all projects with positive net present value. To construct the measurement of investment efficiency, consistent with prior research (Richaerdson, 2006; Biddle et al., 2009; Chen et al., 2011), we build a model which predicts firm's investment efficiency and then use residuals from this model as a proxy for inefficiency investment. In other words, we use this model to measure investment efficiency as deviations from expected investment, which is a function of growth opportunities. We describe the negative deviations from expected investment as underinvestment, the positive deviations from expected investment as overinvestment. Both underinvestment and overinvestment are inefficiency investment. The model is described below:

Investment $_{i, t}=\alpha_{0}+\alpha_{1}$ Growth $_{i, t-1}+\alpha_{2}$ Leverage $_{i, t-1}+\alpha_{3}$ Cash $_{i, t-1}+\alpha_{4}$ Size $_{i, t-1}+\alpha_{5}$ Return $_{i, t-1}+\alpha_{6}$ Age $_{i, t-1}+\alpha_{7}$ Investment $_{i, t-1}+\varepsilon_{i, t}$

where Investment $t_{\mathrm{i}, \mathrm{t}}$ is the sum of capital expenditures, $\mathrm{R} \& \mathrm{D}$ expenditures, and acquisitions minus sales of property, plant, and equipment, scaled by lagged total asset for firm $i$ at the end of year $t-1$. Growth $_{i, t-1}$ is the annual revenue growth rate for firm $i$ at the end of year $t-1$. Leverage $e_{i . t-1}$ is financial leverage, the ratio of long-term debt to the sum of long-term debt plus the market value of equity of firm $i$ at the end of year $t-1$ Cash $_{i . t-1}$ is the ratio of cash to total asset of firm $i$ at the end of year $t-1$. Size $e_{i, t-1}$ is the $\log$ of total assets of firm $i$ at the end of year $t-1$. Return $n_{i, t-1}$ is the stock returns of firm $i$ at the end of year $t-1$. Age $_{i, t-1}$ is the difference between the first year when firm $i$ appears in SZSE (Shenzhen Stock Exchange) at the end of year t-1. Investment $t_{\text {.t. }-1}$ is the lag of investment. 


\subsection{Proxy for financial reporting quality}

The objective of financial reporting is providing the estimation of expected cash flow and the useful information to help investors to make reasonable decisions. Among the disclosed information in financial reporting, accruals quality is one of the most important and comprehensive messages for concerned investors (Echer et al., 2006). Accruals quality is not only an important tool for investors to make investment decisions but also an important foundation for firms' contract design. We proxy for financial reporting quality using measures of accruals quality derived in prior work (Dechow and Dichev, 2002; McNichols, 2002) based on the idea that accruals is estimates of future cash flow. Specifically, we estimate the following model for each industry that has at least 20 observations:

$$
T C A_{i, t}=\beta_{0}+\beta_{1} C F O_{i, t-1}+\beta_{2} C F O_{i, t}+\beta_{3} C F O_{i, t+1}+\beta_{4} \operatorname{Re} v_{i, t}+\beta_{5} P P E_{i, t}++\varepsilon_{i, t}
$$

where TCAi,t is total current accruals; CFO is cash flow from operations; $\operatorname{Rev}_{\mathrm{i}, \mathrm{t}}$ is the annual change in revenues; $\mathrm{PPE}_{\mathrm{i}, \mathrm{t}}$ is property, plant, and equipment.

\subsection{Proxy for free cash flow}

Free cash flow (FCF) is defined as cash flow beyond what is necessary to maintain assets in place (including servicing existing debt) and to finance expected new investments (Richardson, 2006). Michael Jensen (1986) noted that free cash flows allowed firms' managers to finance projects earning low returns which therefore might not be funded by the equity or bond markets. We can measure free cash flow as follows:

$$
F C F=C F O-I_{\text {maintenance }}-I_{\text {new }}^{*}+R D
$$

where FCF is free cash flow, $\mathrm{CFO}$ is operating cash flow, $\mathrm{I}_{\text {maintenance }}$ is a measure of investment expenditure necessary to maintain to assets in place, $\mathrm{I}_{\text {new }}$ is a measure of the expect level of new investment expenditure, $\mathrm{RD}$ refers to research and development expenditure.

\section{Research design and results}

\subsection{Empirical models}

Because we are interested in how financial reporting quality affects investment efficiency, especially how it affects investment for firms with free cash flow, we test our hypothesis by regressing the measure of investment efficiency in year $t$ on the measure of financial reporting quality (FRQ) and free cash flow (FCF) in year t-1. Similar to Biddle et al. (2009), Chen et al. (2011), Ramalingegowda et al.(2013), we also estimate Equation (4) and Equation (5) separately for underinvestment and overinvestment. The empirical models are as follows:

$$
\begin{aligned}
\text { OverI }_{i, t} \text { orUnderI }_{i, t} & =\gamma_{0}+\gamma_{2} \text { FRQ }_{i, t-1}++\gamma_{3} \text { Size }_{i, t-1}+\gamma_{4} \text { Growth }_{i, t-1}+\gamma_{5} \text { Lev }_{i, t-1}+\gamma_{6} \text { Pay }_{i, t-1}+\gamma_{7} \text { Mfe }_{i, t-1} \\
& +\gamma_{8} \text { Vfo }_{i, t-1}+\gamma_{9} \text { State }_{i, t-1}+\sum \text { Industry }+\sum \text { Year }+\varepsilon_{i t} \\
\text { OverI }_{i, t} \text { orUnderI }_{i, t}= & \gamma_{1}+\gamma_{2} F R Q_{i, t-1}+\gamma_{3} F C F_{i, t-1}+\gamma_{4} F R Q_{i, t-1} * \text { DumFCF }_{i, t-1}+\gamma_{5} \text { Size }_{i, t-1}+\gamma_{6} \text { Growth }_{i, t-1} \\
& +\gamma_{7} \text { Lev }_{i, t-1}+\gamma_{8} \text { Pay }_{i, t-1}+\gamma_{9} \text { Mfe }_{i, t-1}+\gamma_{10} \text { Vfo }_{i, t-1}+\gamma_{11} \text { State }_{i, t-1}+\sum \text { Industry }+\sum \text { Year }+\varepsilon_{i t}
\end{aligned}
$$

where:

Over $_{\mathrm{i}, \mathrm{t}}=$ positive excess investment, which is the residual of the investment model as described above.

UnderI $\mathrm{I}_{\mathrm{i}, \mathrm{t}}=$ negative excess investment, which equals the absolute value of the residual of the investment model as described above. 
$\mathrm{FRQ}_{\mathrm{i}, \mathrm{t}-1}=$ financial reporting quality which is the absolute residual of the modified Dechow and Dichev (2002) model, multiplied by -1 .

$\mathrm{FCF}_{\mathrm{i}, \mathrm{t}-1}=$ free cash flow which is beyond what is necessary to maintain assets in place (including servicing existing debt) and to finance expected new investments.

Motivated by prior research, we include the $\log$ of firm size $\left(\operatorname{Size}_{\mathrm{i}, \mathrm{t}-1}\right)$, annual revenue growth rate $\left(\right.$ Growth $\left._{i, t-1}\right)$, financial leverage $\left(\operatorname{Lev}_{\mathrm{i}, \mathrm{t}-1}\right)$, the $\log$ of executive compensation $\left(\mathrm{Pay}_{\mathrm{i}, \mathrm{t}-1}\right)$, the ratio of administrative expenses which scaled by total assets $\left(\mathrm{Mfe}_{\mathrm{i}, \mathrm{t}-1}\right)$, operations cash flow scaled by total assets $\left(\mathrm{Vfo}_{\mathrm{i}, \mathrm{t}-1}\right)$, the nature of equity $\left(\mathrm{State}_{\mathrm{i}, \mathrm{t}-1}\right)$ as control variables, as well as industry fixed effects.

\subsection{Descriptive statistics and correlations}

Table 1 provides descriptive statistics and correlations for our measures of investment efficiency, financial reporting quality (FRQ), free cash flow (FCF) and our main control variables. Panel A shows that the sample consists of 3,726 firms-year observations. In this sample, there are 2,109 $(1,617)$ firms belong to the underinvestment (overinvestment) group. The mean (median) value for underinvestment is $0.072(0.049)$ and for overinvestment is $0.085(0.057)$. These indicate that underinvestment firms are more than overinvestment samples, while overinvestment firms whose inefficiency degree is more serious than that of underinvestment firms. The mean value for financial reporting quality (FRQ) is 0.603 and its median is 0.612 , which shows that the general financial reporting quality is good in listed firms in China. The mean value for free cash flow is 0.124 and its median is 0.109 . Finally, we include descriptive statistics on firm size, sales growth and other control variables. Panel B presents Pearson (Spearman) correlations for underinvestment and financial reporting quality and the main control variables in Panel A. We can see in Panel B that the coefficient between underinvestment and financial reporting quality is -0.092 . This result preliminarily forecasts financial reporting quality is negatively associated with underinvestment. It presents preliminary evidence for the relationship between financial reporting quality and underinvestment in hypothesis H1. Panel C presents Pearson (Spearman) correlations for overinvestment and financial reporting quality and the main control variables in Panel A. We can see in Panel $\mathrm{C}$ that the coefficient between overinvestment and financial reporting quality is -0.113 . This result preliminarily forecasts financial reporting quality is negatively associated with overinvestment. It presents preliminary evidence for the relation between financial reporting quality and overinvestment in hypothesis H2. In addition, both underinvestment samples and overinvestment samples, the Pearson (Spearman) correlation coefficients between variables are low, therefore the samples we selected do not exist multi-collinearity.

Table 1. Descriptive Statistics and Correlations

Panel A: Descriptive Statistics

\begin{tabular}{lllllll}
\hline Variable & OBS & Mean & Median & STD & Min & Max \\
\hline Total I & 3,726 & 0.078 & 0.052 & 0.114 & 0.000 & 1.307 \\
UnderI & 2,109 & 0.072 & 0.049 & 0.121 & 0.000 & 1.307 \\
OverI & 1,617 & 0.085 & 0.057 & 0.106 & 0.000 & 0.968 \\
FRQ & 3,726 & 0.603 & 0.612 & 0.078 & 0.034 & 0.985 \\
FCF & 3,726 & 0.124 & 0.109 & 0.861 & 0.000 & 0.564 \\
Size & 3,726 & 21.32 & 20.78 & 0.973 & 10.27 & 35.79 \\
Growth & 3,726 & 0.155 & 0.147 & 0.382 & -0.461 & 0.867 \\
Lev & 3,726 & 0.572 & 0.594 & 0.793 & 0.000 & 1.241 \\
Pay & 3,726 & 12.56 & 12.61 & 0.943 & 8.350 & 15.52 \\
Mfe & 3,726 & 0.069 & 0.046 & 0.178 & 0.000 & 3.924 \\
Vfo & 3,726 & 0.063 & 0.055 & 0.076 & 0.006 & 0.437 \\
State & 3,726 & 0.616 & 1.000 & 0.587 & 0.000 & 1.000 \\
\hline
\end{tabular}


Panel B: Pearson Correlations Variables through Underli,t.

\begin{tabular}{lllllllllll}
\hline & UnderI & FRQ & FCF & Size & Growth & Lev & Pay & Mfe & Vfo & State \\
\hline UnderI & 1 & & & & & & & & \\
FRQ & -0.092 & 1 & & & & & & & & \\
FCF & 0.016 & 0.035 & 1 & & & & & & & \\
Size & -0.103 & 0.231 & 0.519 & 1 & & & & & & \\
Growth & 0.121 & -0.084 & 0.237 & 0.155 & 1 & & & & & \\
Lev & 0.086 & -0.073 & 0.008 & 0.286 & 0.035 & 1 & & & & \\
Pay & -0.112 & -0.025 & 0.236 & 0.314 & 0.089 & -0.047 & 1 & & & \\
Mfe & 0.527 & -0.063 & 0.145 & 0.109 & 0.075 & 0.044 & -0.468 & 1 & & \\
Vfo & 0.045 & -0.016 & 0.224 & 0.182 & 0.403 & 0.024 & 0.061 & 0.029 & 1 & \\
State & -0.041 & 0.005 & 0.231 & 0.113 & 0.126 & 0.098 & 0.372 & -0.009 & 0.027 & 1 \\
\hline
\end{tabular}

Panel C: Pearson Correlations Variables through OverIi,t.

\begin{tabular}{lllllllllll}
\hline & OverI & FRQ & FCF & Size & Growth & Lev & Pay & Mfe & Vfo & State \\
\hline OverI & 1 & & & & & & & & & \\
FRQ & -0.113 & 1 & & & & & & & & \\
FCF & 0.152 & 0.038 & 1 & & & & & & & \\
Size & 0.235 & 0.158 & 0.492 & 1 & & & & & & \\
Growth & 0.008 & -0.069 & 0.301 & 0.198 & 1 & & & & & \\
Lev & -0.015 & -0.287 & 0.114 & 0.331 & 0.042 & 1 & & & & \\
Pay & -0.063 & -0.014 & 0.229 & 0.254 & 0.129 & -0.081 & 1 & & & \\
Mfe & 0.452 & 0.006 & 0.313 & 0.162 & 0.094 & 0.057 & -0.337 & 1 & & \\
Vfo & 0.076 & -0.004 & 0.294 & 0.206 & 0.195 & 0.043 & 0.082 & 0.067 & 1 & \\
State & 0.424 & -0.055 & 0.403 & 0.189 & 0.097 & 0.072 & 0.346 & -0.022 & 0.003 & 1 \\
\hline
\end{tabular}

Variable Definitions:

Total I $=$ the absolute values of the residuals from the investment efficiency model;

UnderI $=$ absolute value of the negative residuals from the investment efficiency model;

OverI = positive residuals from the investment efficiency model;

FRQ = financial reporting quality, the absolute residual of the modified Dechow-Dichev model as implemented by Francis et al. (2005) and Srinidhi and Gul (2007), multiplied by -1 ;

$\mathrm{FCF}=$ free cash flow, the operating cash flow minus plus research and development expenditure, minus the investment expenditure necessary to maintain to assets in place and expect level of new investment expenditure;

Size $=$ the $\log$ of total assets;

Growth $=$ the annual revenue growth rate;

Lev $=$ financial leverage, the ratio of long-term debt to the sum of long-term debt plus the market value of equity;

Pay $=$ the $\log$ of executive compensation;

$\mathrm{Mfe}=$ the ratio of administrative expenses scaled by total assets;

$\mathrm{Vfo}=$ the ratio of operations cash flow scaled by total assets;

State $=$ the nature of equity. 
Table 2. Financial Reporting Quality, Free cash flow, and Investment Efficiency

\begin{tabular}{|c|c|c|c|c|}
\hline & \multicolumn{2}{|c|}{ Underinvestment } & \multicolumn{2}{|c|}{ Overinvestment } \\
\hline & (A) & (B) & (C) & (D) \\
\hline Constant & $\begin{array}{l}0.178 * * * \\
(3.06)\end{array}$ & $\begin{array}{l}0.244^{*} \\
(4.56)\end{array}$ & $\begin{array}{l}0.221 * * * \\
(4.77)\end{array}$ & $\begin{array}{l}0.451 * * \\
(6.78)\end{array}$ \\
\hline FRQi,t-1 & $\begin{array}{l}-0.045 * * * \\
(-2.75)\end{array}$ & $\begin{array}{l}-0.069^{* *} \\
(-3.27)\end{array}$ & $\begin{array}{l}-0.068 * * * \\
(-3.29)\end{array}$ & $\begin{array}{l}-0.116^{* * *} \\
(-4.65)\end{array}$ \\
\hline FCFi,t-1 & & $\begin{array}{l}0.114 \\
(1.69)\end{array}$ & & $\begin{array}{l}0.183 * * * \\
(4.09)\end{array}$ \\
\hline $\begin{array}{l}\text { FRQi,t- } \\
1 \text { *DumFCFi,t-1 }\end{array}$ & & $\begin{array}{l}0.073 \\
(1.26)\end{array}$ & & $\begin{array}{l}-0.097 * * * \\
(-2.86)\end{array}$ \\
\hline Size i,t-1 & $\begin{array}{l}-0.157 \\
(-1.96)\end{array}$ & $\begin{array}{l}-0.142 * * \\
(-3.95)\end{array}$ & $\begin{array}{l}0.225^{*} \\
(4.26)\end{array}$ & $\begin{array}{l}0.125 \\
(5.53)\end{array}$ \\
\hline Growthi,t-1 & $\begin{array}{l}0.083 * * \\
(4.28)\end{array}$ & $\begin{array}{l}0.130^{*} \\
(4.88)\end{array}$ & $\begin{array}{l}0.011 * * * \\
(12.67)\end{array}$ & $\begin{array}{l}0.322 * * \\
(9.76)\end{array}$ \\
\hline Levi,t-1 & $\begin{array}{l}0.104 * * \\
(9.39)\end{array}$ & $\begin{array}{l}0.104^{* * * *} \\
(6.27)\end{array}$ & $\begin{array}{l}-0.009^{*} \\
(-5.83)\end{array}$ & $\begin{array}{l}-0.118 * * \\
(-4.62)\end{array}$ \\
\hline Payi,t-1 & $\begin{array}{l}-0.007 * * * \\
(-2.67)\end{array}$ & $\begin{array}{l}-0.212 * * \\
(-5.52)\end{array}$ & $\begin{array}{l}-0.074 \\
(-3.36)\end{array}$ & $\begin{array}{l}-0.099 * * \\
(4.13)\end{array}$ \\
\hline Mfei,t-1 & $\begin{array}{l}0.253 \\
(1.96)\end{array}$ & $\begin{array}{l}0.138 \\
(3.94)\end{array}$ & $\begin{array}{l}0.135^{* *} \\
(4.17)\end{array}$ & $\begin{array}{l}0.105 \\
(2.37)\end{array}$ \\
\hline Vfoi,t-1 & $\begin{array}{l}0.080 \\
(1.66)\end{array}$ & $\begin{array}{l}0.107 * * \\
(7.43)\end{array}$ & $\begin{array}{l}0.065^{* * *} \\
(3.92)\end{array}$ & $\begin{array}{l}0.104 * * * \\
(5.21)\end{array}$ \\
\hline Statei,t-1 & $\begin{array}{l}-0.034 \\
(-1.92)\end{array}$ & $\begin{array}{l}-0.146 \\
(-1.81)\end{array}$ & $\begin{array}{l}0.036^{* *} \\
(7.97)\end{array}$ & $\begin{array}{l}0.296^{* *} \\
(7.74)\end{array}$ \\
\hline Industry & Yes & Yes & Yes & Yes \\
\hline Year & Yes & Yes & Yes & Yes \\
\hline Adjust R2 & 0.079 & 0.067 & 0.052 & 0.093 \\
\hline F Value & $20.82 * * *$ & 27.18 & $18.94 * * *$ & $29.66^{* * *}$ \\
\hline $\mathbf{N}$ & 2,109 & 2,109 & 1,617 & 1,617 \\
\hline
\end{tabular}

Note: ${ }^{* * *}, * * *$ Denote significance at the 10 percent, 5 percent, and 1 percent levels, respectively.

\subsection{Results}

Table 2-(A) and (C) report the multiple regressions testing hypothesis $\mathrm{H} 1$ and $\mathrm{H} 2$. The estimated model is a regression of underinvestment (overinvestment) on financial reporting quality, firm characteristics, and industry and year fixed effects. Because our samples contain unbalanced panel data including time-series and cross-section data, we use 2008-2012 data to measure underinvestment efficiency and overinvestment efficiency in response to the measurement financial reporting quality from 2007 to 2011. As can be seen from (A) and (C), the regression coefficients of financial reporting quality are negative, and are significantly under the $1 \%$ significance level. The estimated coefficients suggest that moving from bottom to top decile of financial reporting quality (FRQ) is associated with a reduction on underinvestment of $4.5 \%$. Given the mean of underinvestment is $7.2 \%$ the effect is economically significant. It indicates that financial reporting is negatively associated with underinvestment and overinvestment, which means that high financial reporting quality can reduce moral hazard and adverse selection between the managers and investors. As a result, high financial reporting quality can reduce underinvestment and overinvestment leading to increase investment efficiency which strongly support the hypothesis $\mathrm{H} 1$ and $\mathrm{H} 2$.

Table 2-(B) and (D) report the empirical results of financial reporting quality, free cash flow, and investment efficiency. As before, our empirical models include the control variables such as firm size, sales growth and other firm characteristics, industry and year fixed effects. As can be seen in Panel B, in firms that overinvestment and that have large free cash flow in the sample, the 
FRQ effect on investment efficiency is given by. It indicates that the firms with large free cash flow, the FRQ effect is negative and significant $(-0.213)$ and is lower than for firms with large free cash flow (-0.116), which means that the interaction effect between financial reporting quality (FRQ) and large free cash flow (FCF) play a positive role in reducing the overinvestment efficiency. In firms that underinvestment that have large free cash flow, the FRQ effect on investment is close zero. And the estimated coefficient on the interaction term (FRQ $\mathrm{i}_{\mathrm{i} \mathrm{t}^{-}}$ $1 *$ DumFCF $\left.F_{i, t-1}\right)$ is positive but not significant for underinvestment group. Thus, we cannot conclude that financial reporting quality plays a stronger role in mitigating overinvestment for firms with large free cash flow. In a word, we can see in Panel B which present consistent with results with Hypothesis H3. As we described above, firms with large free cash flow face agency conflicts and higher financial quality is strongly negative with overinvestment. Our result shows that financial reporting quality (FRQ) plays a more important monitoring role in reducing information asymmetry arising from agency conflicts between the managers and investors for firms with large free cash flow.

\section{Conclusions}

Despite recent papers claim that financial reporting quality can have economic implications for investment efficiency, there is little empirical evidence from emerging markets. This paper studies the relation between financial reporting quality, free cash flow, and investment efficiency in Chinese listed firms. The analysis is done on a sample of 3,726 firm-year observations during the period from 2008 to 2012. We find evidence that financial reporting quality is negatively associated with both underinvestment and overinvestment for our sample firms. Further, we find that the relation between financial reporting quality and overinvestment is stronger for firms with high free cash flows, which suggests that financial reporting quality can reduce the information asymmetry between managers and investors and thus lower shareholders' cost of monitoring managers and improving project selection.

Our study provides new evidence that financial reporting quality plays an important role in investment efficiency in emerging markets. Specifically, financial reporting quality plays a more important role in overinvestment for firms with much free cash flow. Our study also is subject to some caveats. Firstly, we acknowledge that the investment efficiency, the financial reporting quality and the free cash flow variables likely suffer from measurement error. Second, our results do not necessarily generalize to all emerging markets because of China's special institutional background.

\section{Acknowledgement}

*This study was funded by grants from the National Natural Science Foundation of China (Nos.70972097, 71031003) and Social Science Foundation of Heilongjiang Province (Nos.14C011). We are grateful to the good research condition provided by Said Business School, University of Oxford.

\section{References}

1. Balakrishnan K., J. Core, and R. S. Veri. The relation between reporting quality and financing and investment: evidence from shocks to financing capacity. Journal of Accounting Research. 2014, 54(2): 516-553.

2. Beatty A., S. Liao, and J. Weber. Financial reporting quality, private information, monitoring, and the lease-versus-buy decision. The Accounting Review. 2010, 85(4):1215-1238.

3. Berger, P. G., and R. Han. The impact of SFAS 131 on information and monitoring. Journal of Accounting Research. 2003, 41(1):163-223. 
4. Biddle, G., and G. Hilary. Accounting quality and firm-level capital investment. The Accounting Review. 2006, 81(5): 963-982.

5. Biddle, G., G. Hilary, and R. S. Verdi. 2009. How does financial reporting quality relate to investments efficiency? Journal of Accounting and Economics.2009, 48(2-3): 112-131.

6. Bushman, R., and A. Smith. Financial accounting information and corporate governance. Journal of Accounting and Economics. 2001, 31(1-3): 237-333.

7. Chen, F., O. Hope, Q. Li, and X. Wang. 2011. Financial reporting quality and investment efficiency of private firms in emerging markets. The Accounting Review. 2011, 86(3): 12551288.

8. Dechow, P., and I. Dichev. The quality of accruals and earnings: The role of accrual estimation errors. The Accounting Review 77 (Supplement), 2002: 35-59.

9. Gomariz F., Ballesta J. Financial reporting quality, debt maturity and investment efficiency. Journal of Banking and Finance. 2014, 40(2): 4945-06.

10. Francis, J., R. LaFond, P. Olsson, and K. Schipper. The market pricing of accruals quality. Journal of Accounting and Economics. 2005, 39(2): 295-327.

11. Harford, J. Corporate cash reserves and acquisitions Journal of Finance. 1999, 54(5): 19691997

12. Healy, P., and K. Palepu. 2001. Information asymmetry, corporate disclosure, and the capital markets: A review of the empirical disclosure literature. Journal of Accounting and Economics. 2001, 31(1-3): 405-440.

13. Hope, O.K., and W. B. Thomas. Managerial empire building and firm disclosure. Journal of Accounting Research. 2008, 46(3): 591-626.

14. Jensen, M. C. Agency costs of free cash flow, corporate finance, and takeovers. American Economic Review. 1986, 769(1): 323-329.

15. Lamont, O. Cash flow and investment: Evidence from internal capital markets. Journal of Finance. 1997,52(1): 83-109.

16. Lambert, R., C. Leuz, and R. E. Verrecchia. Accounting information, disclosure, and the cost of capital. Journal of Accounting Research. 2007, 45(2): 385-420.

17. McNichols, M. F., and S. R. Stubben. Does earnings management affect firms' investment decisions? The Accounting Review. 2008, 83(6): 1571-1603.

18. Miller, M. H., and F. Modigliani. Dividend policy, growth, and the valuation of shares. Journal of Business. 1961, 34(4): 411-433.

19. Mørck, R., A. Shleifer, and R. W. Vishny. Management ownership and market valuation: an empirical analysis. Journal of Financial Economics. 1988, 20(1): 293-315.

20. Morck, R., A. Shleifer, and R. W. Vishny. Do managerial objectives drive bad acquisitions? Journal of Finance. 1990, 45(1): 31-48.

21. Opler, T., L. Pinkowitz, R. Stulz, and R. Williamson. Corporate cash holdings. Journal of Applied Corporate Finance. 2001, (14): 55-66.

22. Ramalingegowda S, C. Wang, and Y. Yu. The Role of financial reporting quality in mitigating the constraining effect of dividend policy on investment decisions. The Accounting Review. 2013, 88(3): 1007-1039.

23. Richardson, S. Over-investment of free cash flow. Review of Accounting Studies. 2006, 11(23): 159-189. 